\title{
Altered expression of PTCH and HHIP in gastric cancer through their gene promoter methylation: Novel targets for gastric cancer
}

\author{
YU SONG ${ }^{1,2}$, YE TIAN ${ }^{1}$, YUN ZUO $^{2}$, JIAN-CHENG TU ${ }^{2}$ \\ YU-FANG FENG ${ }^{2}$ and CHEN-JIANG QU ${ }^{2}$ \\ ${ }^{1}$ Department of Radiotherapy and Oncology, The Second Affiliated Hospital of Soochow University, Suzhou; \\ ${ }^{2}$ Department of Radiotherapy and Oncology, The First People's Hospital of Zhangjiagang, \\ Zhangjiagang, Jiangsu, P.R. China
}

Received January 14, 2013; Accepted February 15, 2013

DOI: $10.3892 / \mathrm{mmr} .2013 .1333$

\begin{abstract}
Human hedgehog-interacting protein (HHIP) and protein patched homolog $(\mathrm{PTCH})$ are two negative regulators of the hedgehog signal, however, the mechanism of action in gastric cancer is unknown. Methylation of TSG promoters has been considered as a causative mechanism of tumorigenesis. In the present study, we first determined the expression of PTCH and HHIP mRNA and protein in gastric cancer tissues and adjacent normal tissues, and then detected methylation of the two genes to associate their expression and gene promoter methylation in gastric cancer. Expression in gastric cancer tissues and the cancer cells (AGS) were evaluated by reverse transcription-PCR (RT-PCR), qRT-PCR and IHC, while the methylation expression was valued by methylation-specific PCR (MSP) and bisulfite sequencing PCR (BSP). Cell viability and apoptosis were analyzed by MTT assay and flow cytometry following treatment with 5-aza-dc. Results showed that PTCH and HHIP expression was reduced in gastric cancer tissues that were not associated with clinical features. Moreover, methylation of the promoters was reversely correlated with the expression. Following treatment with 5-aza-dc, AGS reduced cell viability and induced apoptosis, which is associated with upregulation of HHIP expression. The data demonstrated that loss of expression of HHIP and PTCH is associated with the methylation of gene promoters. In addition, 5-aza-dc-induced apoptosis correlated with the upregulation of HHIP expression in AGS. The findings demonstrated that the PTCH and HHIP genes may be novel targets for the control of gastric cancer.
\end{abstract}

Correspondence to: Dr Ye Tian, The Second Affiliated Hospital of Soochow University, San Xiang Road No. 1055, Suzhou, Jiangsu 215004, P.R. China

Email: dryetian@hotmail.com

Key words: human hedgehog-interacting protein, protein $\mathrm{PTCH}$ homolog, gastric cancer, methylation

\section{Introduction}

Gastric cancer is one of the most common cancers worldwide, accounting for the fourth most frequent malignancy and the second cause of cancer-related mortality annually (1).Gastric cancer is usually diagnosed in the later stages of the disease and has poor prognosis due to insufficient therapeutic options for patients with unresectable, metastatic, or recurrent gastric cancer. Therefore, investigation of the molecular mechanisms of gastric carcinogenesis, and the development of novel therapeutic strategies for the control of gastric cancer is crucial. The hedgehog pathway is important in embryonic development, tissue polarity and carcinogenesis (2-4). Gastric cancer development has been associated with a variety of genetic alterations, including genes in the Sonic hedgehog (Shh), Notch, and Wnt signaling pathways (5-9). Recently, aberrant activation of this pathway was described in human gastric tumor biopsies, and a high expression of proteins in the Shh pathway was found in gastric tumor cell lines (10). The canonical hedgehog pathway includes three hedgehog ligands, sonic (SHH), Indian (IHH), and desert (DHH) hedgehog, which bind to $\mathrm{PTCH}$, a 12 transmembrane domain protein that releases smoothened homolog (SMO). SMO subsequently allows Gli family transcription factors to translocate to the nucleus and affect expression of target genes. Human hedgehog-interacting protein (HHIP) was identified by screening a mouse cDNA expression library for proteins that bind to Shh (11). HIP binds all three Hh proteins with an affinity equal to that of Patched-1 (Ptch-1), and functions to negatively regulate the hedgehog pathway. Specifically, expression of the HHIP and PTCH genes, two negative regulators of hedgehog signaling $(12,13)$, has been shown to be reduced in gastric cancer tissues, but retained in normal gastric tissues or atypical hyperplasia (14). However, the clinical significance of their expression loss in gastric cancer, and the underlying mechanism responsible remains to be determined.

DNA methylation is a stable albeit reversible epigenetic change for effective silencing of gene expression (15), and plays a crucial role in normal organism development and cellular differentiation as it can stably alter gene expression patterns in cells. However, it is also thought that somatic alterations in 
DNA methylation patterns contribute to cancer development and aging, particularly the methylation of tumor suppressor gene promoters in the development of human cancer (16). In gastric cancer, DNA methylation of different genes has been studied, including methylation of the PTCH gene transcriptional regulation region (17-20). However, to the best of our knowledge, no study has accurately analyzed the methylation of PTCH and HHIP gene promoters in gastric cancer. In this study, we first determined the expression of PTCH and HHIP mRNA and protein in gastric cancer tissues and adjacent normal tissues, and then detected methylation of these two genes to associate their expression and gene promoter methylation in gastric cancer.

\section{Materials and methods}

Patient tissue samples. Surgical specimens from 30 patients with gastric cancer and adjacent normal tissues were collected from the Department of Surgery, Zhangjiagang First Hospital (Jiangsu, China) between 2008 and 2010. Surgically resected tissue specimens were snap-frozen in liquid nitrogen until use. The specimens were examined by at least two experienced pathologists and tumors were classified according to the tumornode-metastasis (TNM) classification. Patients included 17 males and 13 females with an age range of 36-72 years (mean, 60.82 years). According to the TNM staging system, 20 cases were stage II and 10 cases were stage III. Sixteen tumors were well- and moderately differentiated, while 14 were poorly differentiated. Twelve tumors had lymph node metastasis, but 18 cases were without lymph node metastasis. The study was approved by the Ethical Committee of National Drug Clinical Trial Institution of The Second Affiliated Hospital of Soochow University, and written informed consent was obtained from all participants.

RNA isolation and reverse transcription-PCR (RT-PCR). RNA was isolated from the frozen gastric cancer and normal tissues. Briefly, tissue samples of $\sim 100-300 \mu \mathrm{g}$ were pulverized over liquid nitrogen, placed in a denaturing buffer, and disrupted using a Mixer Mill (Retsch) or rotor-stator homogenizer (Omni International, Kennesaw, GA, USA). RNA was isolated from the homogenate either by using phenol-chloroform extraction followed by precipitation with isopropanol and washing with $70 \%$ ethanol, or using an RNeasy kit (Qiagen, Dusseldorf, Germany). RNA concentration was measured using a spectrophotometer (Hongji, Shanghai, China) and the absorbance was read at $260 \mathrm{~nm}$. cDNA was then converted from RNA using a reverse transcription kit (Jingmei, Shanghai, China) according to the manufacturer's instructions, and stored at $-20^{\circ} \mathrm{C}$. For PCR amplification of gene expression, a $25 \mu \mathrm{l}$ reaction mixture containing $2 \mu \mathrm{l}$ of sample cDNA, $2.5 \mu \mathrm{l}$ 10X PCR reaction buffer, $0.5 \mu \mathrm{l}$ of $10 \mathrm{mM} / \mathrm{l} \mathrm{dNTP}$ intermixture, $0.2 \mu \mathrm{l}$ of $10 \mathrm{mM} / 1$ of each primer, $0.5 \mu \mathrm{l}$ of $5 \mathrm{U} / \mu \mathrm{l}$ Taq DNA polymerase, and $19.1 \mu \mathrm{l} \mathrm{ddH}_{2} \mathrm{O}$. PCR amplification was set for an initial cycle of $94^{\circ} \mathrm{C}$ for $3 \mathrm{~min}$ and 32 cycles of $94^{\circ} \mathrm{C}$ for $30 \mathrm{sec}, 58^{\circ} \mathrm{C}$ for $45 \mathrm{sec}$, and $72^{\circ} \mathrm{C}$ for $45 \mathrm{sec}$ and a final extension at $72^{\circ} \mathrm{C}$ for $10 \mathrm{~min}$. The amplification of each gene was in the linear range. RT-PCR products were then separated on ethidium bromide-stained $2 \%$ agarose gels. The primer sequences for PTCH, HHIP, and $\beta$-actin genes are listed in Table I.
Quantitative RT-PCR using the ABI PRISM ${ }^{\mathrm{TM}} 7700$ Sequence Detection System and TaqMan ${ }^{\mathrm{TM}}$ chemistry was also performed. Reactions contained $0.3 \mu \mathrm{l}$ of each primer, $0.1 \mu \mathrm{l}$ cDNA, $0.25 \mathrm{U} / \mathrm{ml}$ MultiScribe reverse transcriptase, $0.4 \mathrm{U} / \mathrm{ml}$ RNase inhibitor, and 1X PCR master mix (Applied Biosystems, Foster City, CA, USA). qRT-PCR data were quantified using the comparative $\mathrm{CT}$ method (i.e., $\mathrm{CT}$ values were normalized to the housekeeping gene $\beta$-actin). The melting curve was analyzed to ensure the specificity of the PCR products. The RQ values of PTCH and HHIP expression in tumor samples were compared to that of pooled adjacent normal tissue samples. To ensure experimental accuracy, all reactions were performed in triplicate. The primer sequences of PTCH, HHIP and the $\beta$-actin genes are listed in Table I.

Immunohistochemistry. Representative formalin-fixed and paraffin-embedded tissue sections $(5-\mu \mathrm{m})$ were prepared and used for immunohistochemistry with specific antibodies to PTCH (sc-6149; Santa Cruz Biotechnology Inc., Santa Cruz, CA, USA) and HHIP (sc-25465; Santa Cruz, Biotechnology Inc.). Briefly, the tissue sections were deparaffinized, followed by rehydration with serially decreased concentrations of ethanol, and immersed in $3 \% \mathrm{H}_{2} \mathrm{O}_{2}$ (in distilled water) for $10 \mathrm{~min}$ to inhibit endogenous peroxidase activity. Antigen retrieval was performed in citrate buffer $(\mathrm{pH}$ 6.0) and the tissue sections were incubated with a normal goat serum to block non-specific antibody binding for $20 \mathrm{~min}$ at room temperature. The sections were then incubated with primary antibodies against PTCH (diluted at 1:100) and HHIP (diluted at $1: 50$ ) at $37^{\circ} \mathrm{C}$ in humid chambers for $2 \mathrm{~h}$. After washing 3 times with PBS, the sections were incubated with a biotinylated secondary antibody (the goat anti-rabbit $\mathrm{IgG}$ ) and streptavidin conjugated to horseradish peroxidase for $20 \mathrm{~min}$ at $37^{\circ} \mathrm{C}$, followed by PBS washing. The sections were incubated with DAB substrate for 10 min and counterstained with haematoxylin. Negative controls were performed in all the cases by omitting the primary antibodies. The sections were reviewed under a microscope and scored. Positive staining was reviewed as yellow or brown staining in the stained sections. Each section was counted for 200 cancer cells in five different high-power fields, and the section was reviewed as positive staining if $\geq 5 \%$ tumor cells were stained positively.

DNA isolation and methylation-specific PCR (MSP) and bisulfite sequencing PCR (BSP). DNA was extracted according to the standard protocol. Briefly, $50 \mathrm{mg}$ of tissue specimens were placed into a mortar, (cells were repeatedly washed with PBS buffer via centrifugation), and ground into powder. TE buffer $(1 \mathrm{ml}), 50 \mu \mathrm{l}$ of $10 \% \mathrm{SDS}$, and $2 \mu \mathrm{l}$ of $10 \mathrm{mg} / \mathrm{ml}$ RNase, were added followed by incubation in a $37^{\circ} \mathrm{C}$ water bath for $1 \mathrm{~h}$, and the addition of $5 \mu \mathrm{l}$ of $20 \mathrm{mg} / \mathrm{ml}$ proteinase $\mathrm{K}$ and a subsequent incubation in a $55^{\circ} \mathrm{C}$ water bath overnight. The following day, an equal volume of saturated phenol was added to the tissue mixture and centrifuged at $16,000 \times \mathrm{g}$ for $10 \mathrm{~min}$ at $4^{\circ} \mathrm{C}$. The supernatant was transferred to a new microtube and an equal volume of phenol/chloroform/isopropyl alcohol mixture was then added followed by centrifugation at $16,000 \mathrm{x} \mathrm{g}$ for $10 \mathrm{~min}$ at $4^{\circ} \mathrm{C}$. The supernatant was transferred to a new microtube and the aforementioned protocol was repeated again. The final supernatant was precipitated with two volumes of ethanol and 
Table I. Primers and PCR product size.

\begin{tabular}{|c|c|c|c|c|}
\hline Methods & Primers & $\begin{array}{l}\text { Sequence } \\
\left(5^{\prime}-3^{\prime}\right)\end{array}$ & $\begin{array}{l}\text { Length } \\
\text { (bp) }\end{array}$ & $\begin{array}{l}\text { Temperature } \\
\left({ }^{\circ} \mathrm{C}\right)\end{array}$ \\
\hline \multirow[t]{5}{*}{ RT-PCR } & PTCH & CTGCTGGTATGCTCGGGACTG & 175 & 60 \\
\hline & & TAAATCGCTCGGAGTTTCTGG & & \\
\hline & HHIP & CTGCTTCTGTATTCAGGAGGTT & 229 & 55 \\
\hline & & GGGATGGAATGCGAGGCTTA & & \\
\hline & $\beta$-actin & $\begin{array}{l}\text { AGAGCTACGAGCTGCCTGAC } \\
\text { AGCACTGTGTTGGCGTACAG }\end{array}$ & 184 & 60 \\
\hline \multirow[t]{3}{*}{ BSP } & PTCH & $\begin{array}{l}\text { GGGAGTATTTGGGTGGTATATT } \\
\text { ATTNCTACAAAAAAACACCACCTTTC }\end{array}$ & 349 & 60 \\
\hline & HHIP & $\begin{array}{l}\text { GGGGAGGAGAGAGGAGTTTG } \\
\text { CCCRACRACCTCCCTACTA }\end{array}$ & 243 & 60 \\
\hline & $\beta$-actin & $\begin{array}{l}\text { AGAGCTACGAGCTGCCTGAC } \\
\text { AGCACTGTGTTGGCGTACAG }\end{array}$ & 184 & 60 \\
\hline \multirow[t]{2}{*}{$\begin{array}{l}\text { MSP } \\
\text { (HHIP) }\end{array}$} & Methylation & $\begin{array}{l}\text { GTAGTAGTCGGGTAGTTTCGGAATTTTC } \\
\text { AAAAACGACTAACCGCGACG }\end{array}$ & 190 & 60 \\
\hline & Non-methylation & $\begin{array}{l}\text { AGTAGTTGGGTAGTTTTGGAATTTTTGG } \\
\text { AAAAACAACTAACCACAACA }\end{array}$ & 188 & 60 \\
\hline
\end{tabular}

RT-PCR, reverse transcription-PCR; PTCH, protein patched homolog; HHIP, human hedgehog-interacting protein; BSP, bisulfite sequencing PCR; MSP, methylation-specific PCR.
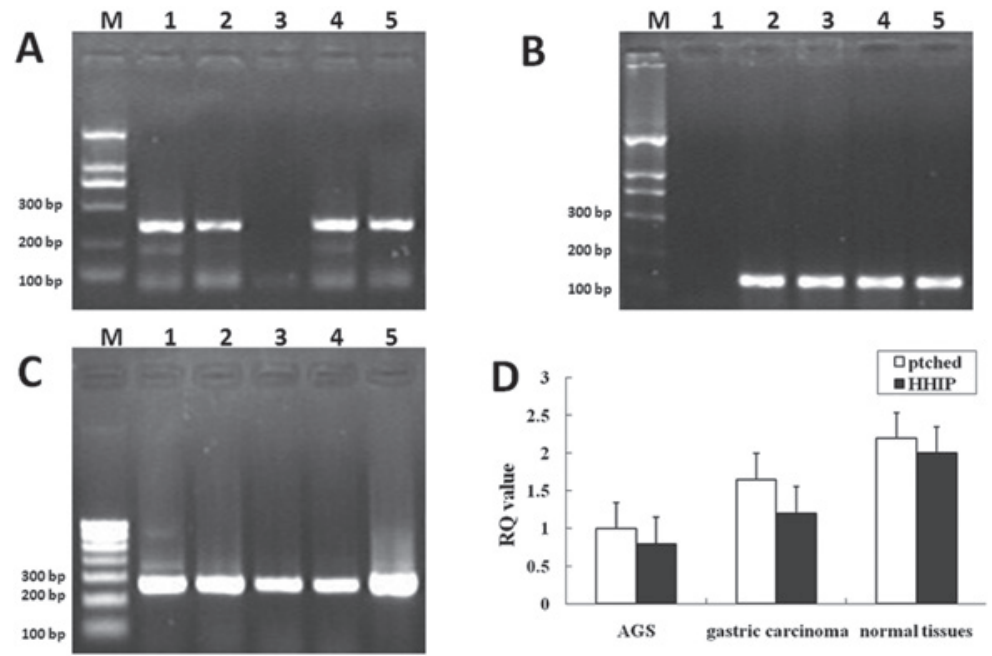

Figure 1. Expression of PTCH and human hedgehog-interacting protein (HHIP) mRNA in gastric cancer tissues and cells. Reverse transcription-PCR (RT-PCR) results for (A) HHIP (B) protein patched homolog (PTCH) and (C) $\beta$-actin. Lane M, marker; lane 1, gastric cancer tissue; lane 2, adjacent normal tissue; lane 3, AGS cells; lane 4, qRT-PCR gastric cancer tissue; lane 5, adjacent normal tissue. (D) qRT-PCR detection of Ptched and HHIP mRNA expression in gastric cancer tissues and cells.

one tenth volume of $3 \mathrm{M}$ sodium acetate at $-20^{\circ} \mathrm{C}$ for $2 \mathrm{~h}$, and centrifuged at $16,000 \mathrm{x}$ g for $10 \mathrm{~min}$ at $4^{\circ} \mathrm{C}$. The supernatant was discarded and then $70 \%$ ethanol was added followed by centrifugation at $16,000 \mathrm{xg}$ for $10 \mathrm{~min}$ at $4^{\circ} \mathrm{C}$. The supernatant was then dissolved in $80 \mu \mathrm{l} \mathrm{TE}$ buffer and stored at $-20^{\circ} \mathrm{C}$ until use.

For MSP and BSP, DNA samples were treated with bisulfite modification as previously described (21). One microgram of genomic DNA was treated using a Beijing Science and Technology Development Co. methylation kit (Beijing, China) according to the manufacturer's instructions. The primers of
MSP and BSP used are shown in Table I. For MSP, $1 \mu 1$ of the modified DNA was amplified using MSP primers that specifically recognized the methylated (M) or unmethylated (U) DNA after bisulfite conversion. CpGnome Universal Methylated DNA (S7821) and CpGnome Universal Unmethylated DNA (S7822) (Chemicon Co., Temecula, CA, USA) were used as the controls for methylated and unmethylated detection, respectively. Amplification products were resolved with $2 \%$ agarose gel electrophoresis and visualized with ethidium bromide staining. For BSP clone sequence analysis, the PCR products were submitted to Shanghai Sangon Co. Ltd. (Shanghai, 
Table II. Expression of PTCH and HHIP mRNA and protein.

\begin{tabular}{|c|c|c|c|c|c|c|c|c|c|}
\hline \multirow[b]{3}{*}{ Tissue } & \multirow[b]{3}{*}{$\mathrm{N}$} & \multicolumn{4}{|c|}{ PTCH expression } & \multicolumn{4}{|c|}{ HHIP expression } \\
\hline & & \multicolumn{2}{|c|}{ mRNA } & \multicolumn{2}{|c|}{ Protein } & \multicolumn{2}{|c|}{ mRNA } & \multicolumn{2}{|c|}{ Protein } \\
\hline & & Positive & Negative & Positive & Negative & Positive & Negative & Positive & Negative \\
\hline Carcinoma & 30 & 12 & 18 & 10 & 20 & 9 & 21 & 9 & 21 \\
\hline Normal tissue & 30 & 25 & 5 & 24 & 6 & 20 & 10 & 18 & 12 \\
\hline$\chi^{2}$ test & & 1.2 & & 3.333 & & 4.8 & & 4.8 & \\
\hline P-value & & 0.273 & & 0.068 & & 0.028 & & 0.028 & \\
\hline
\end{tabular}

PTCH, protein patched homolog; HHIP, human hedgehog-interacting protein.

Table III. Association of PTCH and HHIP mRNA expression with clinicopathological data.

\begin{tabular}{|c|c|c|c|c|c|c|c|}
\hline \multirow[b]{2}{*}{ Clinical characteristics } & \multirow[b]{2}{*}{ Total } & \multicolumn{3}{|c|}{ PTCH } & \multicolumn{3}{|c|}{ HHIP } \\
\hline & & Mean \pm SD & t-test & P-value & Mean \pm SD & t-test & P-value \\
\hline \multicolumn{8}{|l|}{ Gender } \\
\hline Male & 17 & $1.6792 \pm 0.04060$ & -0.387 & 0.706 & $1.3562 \pm 0.02339$ & 0.545 & 0.596 \\
\hline Female & 13 & $1.6983 \pm 0.02637$ & & & $1.3386 \pm 0.01571$ & & \\
\hline \multicolumn{8}{|l|}{ Age (years) } \\
\hline$<50$ & 11 & $1.6867 \pm 0.04767$ & 0.114 & 0.912 & $1.3502 \pm 0.02738$ & 0.012 & 0.991 \\
\hline$\geq 50$ & 19 & $1.6812 \pm 0.02312$ & & & $1.3497 \pm 0.01534$ & & \\
\hline \multicolumn{8}{|l|}{ TNM stage } \\
\hline II & 20 & $1.6841 \pm 0.05262$ & -0.482 & 0.641 & $1.3448 \pm 0.01786$ & -0.031 & 0.976 \\
\hline III & 10 & $1.7084 \pm 0.02553$ & & & $1.3455 \pm 0.01975$ & & \\
\hline \multicolumn{8}{|l|}{ Differentiation } \\
\hline Well and moderate & 16 & $1.7589 \pm 0.01190$ & 2.914 & 0.012 & $1.3543 \pm 0.02174$ & 0.972 & 0.394 \\
\hline Poor & 14 & $1.6410 \pm 0.02906$ & & & $1.3366 \pm 0.01468$ & & \\
\hline \multicolumn{8}{|l|}{ Lymph node metastasis } \\
\hline Yes & 12 & $1.6860 \pm 0.04352$ & -0.370 & 0.718 & $1.3524 \pm 0.02509$ & 0.162 & 0.875 \\
\hline No & 18 & $1.7021 \pm 0.02329$ & & & $1.3489 \pm 0.01705$ & & \\
\hline
\end{tabular}

HHIP, human hedgehog-interacting protein; TNM, tumor-node-metastasis.

China) for subcloning of PCR products and then amplified. Twenty clones were chosen for DNA sequencing by Shanghai Sangon Co. Ltd.

Cell culture and 5-aza-dc treatment. The AGS gastric cancer cell line was purchased from the Shanghai Institute Cell Bank (Shanghai, China) and cultured in RPMI-1640 (Invitrogen, Carlsbad, CA, USA) supplemented with $10 \%$ fetal bovine serum (FBS), streptomycin $100 \mu \mathrm{g} / \mathrm{ml}$, and penicillin $100 \mathrm{U} / \mathrm{ml}$ at $37^{\circ} \mathrm{C}$ in a humidified atmosphere with $5 \% \mathrm{CO}_{2}$. For our experiments, AGS cells were then treated with 5-aza-dc (Sigma, St. Louis, MO, USA) for 3 days and the control cells were cultured with an equivalent volume of dimethyl sulfoxide (DMSO).

Cell viability MTT assay. Exponentially growing cells $\left(2 \times 10^{3} / 200 \mu \mathrm{l} /\right.$ well $)$ were seeded in 96 -well plates and were grown up to 4 days. The surviving cells were evaluated by adding $50 \mu \mathrm{l}$ of $2.5 \mathrm{mg} / \mathrm{ml} \mathrm{3-(4,5-dimethylthiazol-2-yl)-}$ 2,5-diphenyltetrazolium bromide (MTT; Sigma) in DMSO into the culture medium and incubated for $4 \mathrm{~h}$ at $37^{\circ} \mathrm{C}$ in the dark. Subsequently, the culture medium was removed and $100 \mu \mathrm{l}$ of DMSO were added into the plates and absorbance was measured at $570 \mathrm{~nm}$ with a microplate reader (Bio-Rad, Hercules, CA, USA).

Annexin V/PI-flow cytometry assay. AGS gastric cancer cells were grown and treated with or without 5-aza-dc for 3 days. Approximately $1 \times 10^{6}$ AGS cells were centrifuged at $400 \mathrm{x} \mathrm{g}$ for $10 \mathrm{~min}$ to remove the culture medium. Buffer $(20 \mathrm{ml})$ and 60 $\mathrm{ml}$ deionized water were added to the cells, and then the cells were centrifuged at $400 \mathrm{x}$ g for $5 \mathrm{~min}$ and washed with PBS.

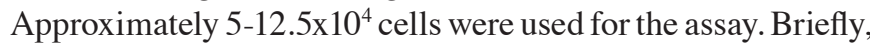
the cells were re-suspended in $195 \mu \mathrm{l}$ of binding buffer to reach a final concentration of $2-5 \times 10^{5}$ cells $/ \mathrm{ml}$. Annexin V/FITC 


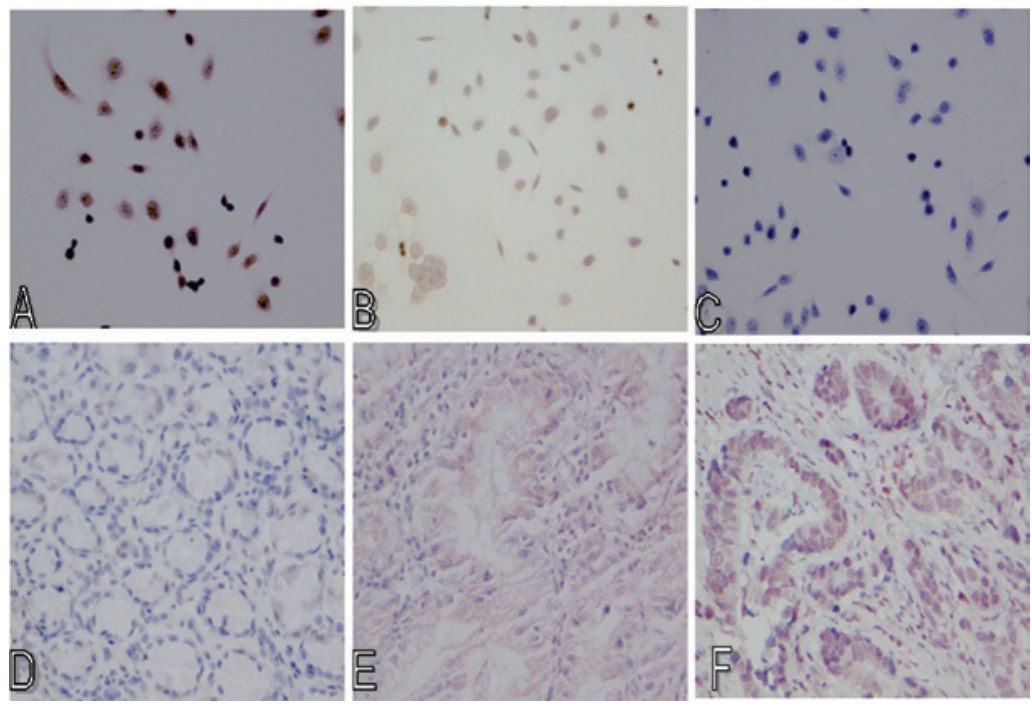

Figure 2. Immunohistochemical analysis of PTCH and human hedgehog-interacting protein (HHIP) expression in gastric cancer and normal tissues and cells. (A) AGS protein PTCH homolog 1 (PTCH1)-positive, (B) AGS HHIP-positive, (C) AGS-negative, (D) gastric cancer-negative, (E) gastric cancer Ptched-positive and (F) gastric cancer HHIP-positive.

Table IV. Association of PTCH and HHIP mRNA levels with their protein expression.

\begin{tabular}{|c|c|c|c|c|c|}
\hline \multirow[b]{2}{*}{ PTCH mRNA } & \multicolumn{2}{|c|}{ PTCH protein } & \multirow[b]{2}{*}{ HHIP mRNA } & \multicolumn{2}{|c|}{ HHIP protein } \\
\hline & Positive & Negative & & Positive & Negative \\
\hline Positive & 32 & 5 & Positive & 26 & 3 \\
\hline Negative & 2 & 21 & Negative & 1 & 30 \\
\hline Pearson correlation & $\begin{array}{l}r=0.902 \\
P=0.000\end{array}$ & & Pearson's correlation & $\begin{array}{l}\mathrm{r}=0.935 \\
\mathrm{P}=0.000\end{array}$ & \\
\hline
\end{tabular}

PTCH, protein patched homolog; HHIP, human hedgehog-interacting protein.

Table V. Immunohistochemistry expression of PTCH and HHIP in different clinical and pathological features.

\begin{tabular}{|c|c|c|c|c|c|c|c|c|c|}
\hline \multirow[b]{2}{*}{ Clinical features } & \multirow[b]{2}{*}{ Total } & \multicolumn{4}{|c|}{ PTCH } & \multicolumn{4}{|c|}{ HHIP } \\
\hline & & Positive & Negative & $\chi^{2}$ test & P-value & Positive & Negative & $\chi^{2}$ test & P-value \\
\hline \multicolumn{10}{|l|}{ Gender } \\
\hline Male & 17 & 5 & 12 & 0.533 & 0.144 & 4 & 13 & 0.533 & 0.465 \\
\hline Female & 13 & 5 & 8 & & & 5 & 8 & & \\
\hline \multicolumn{10}{|l|}{ Age (years) } \\
\hline$<50$ & 11 & 4 & 7 & 2.133 & 0.144 & 5 & 6 & 2.133 & 0.144 \\
\hline$\geq 50$ & 19 & 6 & 13 & & & 4 & 15 & & \\
\hline \multicolumn{10}{|l|}{ TNM stage } \\
\hline II & 20 & 7 & 13 & 3.333 & 0.068 & 5 & 15 & 2.133 & 0.144 \\
\hline III & 10 & 3 & 7 & & & 4 & 6 & & \\
\hline \multicolumn{10}{|l|}{ Differentiation } \\
\hline Well and moderate & 16 & 6 & 10 & 0.133 & 0.715 & 6 & 10 & 0.133 & 0.715 \\
\hline Poor & 14 & 4 & 10 & & & 3 & 11 & & \\
\hline \multicolumn{10}{|c|}{ Lymph node metastasis } \\
\hline Yes & 12 & 5 & 7 & 1.2 & 0.273 & 2 & 10 & 1.2 & 0.273 \\
\hline No & 18 & 5 & 13 & & & 7 & 11 & & \\
\hline
\end{tabular}

HHIP, human hedgehog-interacting protein; TNM, tumor-node-metastasis. 

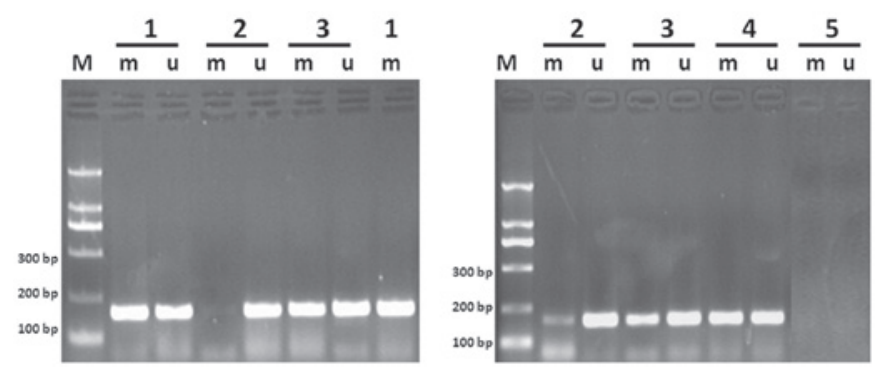

Figure 3. Methylation-specific PCR analysis of human hedgehog-interacting protein (HHIP) gene promoter methylation. Lane 1, AGS cell; lane 2, gastric cancer tissue; lane 3, adjacent normal tissue; lane 4, positive control; lane 5, negative control. $\mathrm{M}$, methylated; $\mathrm{U}$, unmethylated.

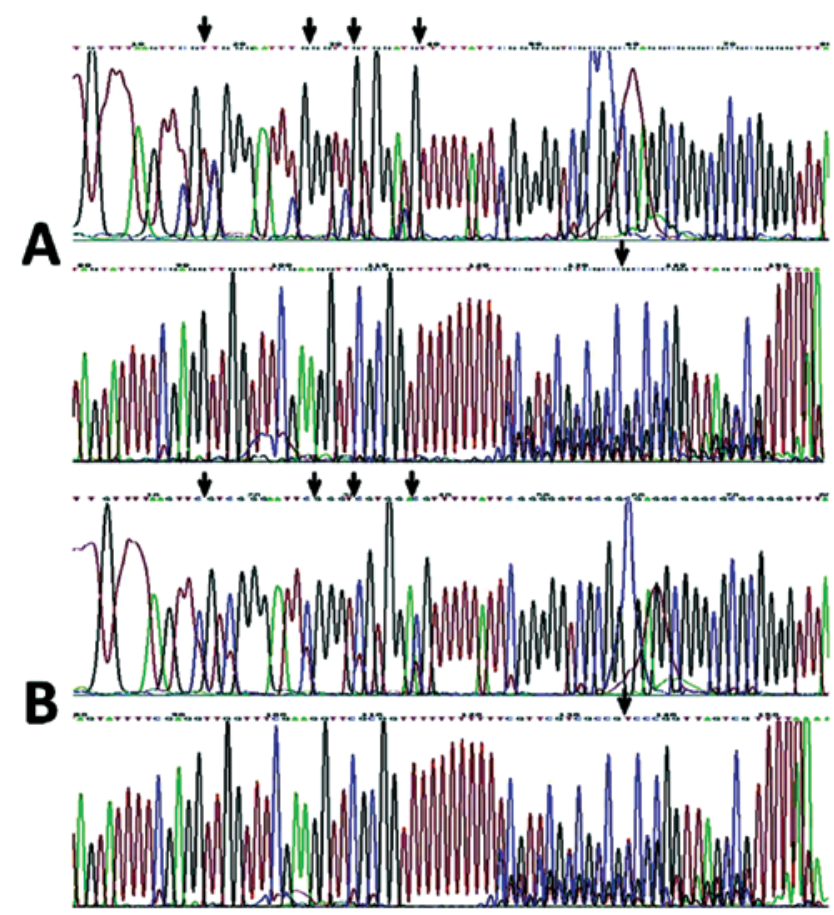

Figure 4. (A) The sequence of the methylated clones of methylation-specific PCR (MSP) product of human hedgehog-interacting protein (HHIP) gene in gastric cancer. (B) The sequence of the unmethylated clones of MSP product of HHIP gene in gastric cancer.

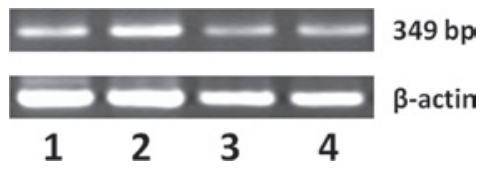

Figure 5. Bisulfite sequencing PCR (BSP) analysis of Ptched expression in gastric cancer and normal tissues and cells. Lane 1, AGS; lane 2, gastric cancer; lane 3, normal tissues; lane 4, gastric cancer.

(5 $\mu \mathrm{l}$; from BD Biosciences, Franklin Lakes, NJ, USA) was added and incubated for $10 \mathrm{~min}$ at room temperature in the dark. After washing with binding buffer, $10 \mu \mathrm{l}$ of propidium iodide (PI, $20 \mu \mathrm{g}$ ) was added to the cell solution. The apoptosis rate was measured with a flow cytometer (Human Biotech, Shanghai, China), and the data were summarized as mean \pm SD compared to the control cells.
Table VI. Association of PTCH expression with the gene promoter methylation.

\begin{tabular}{lcc}
\hline & PTCH expression & Methylation \\
\hline Cancer & $1.7537 \pm 1.15046$ & $0.5700 \pm 0.31724$ \\
Normal tissues & $2.7993 \pm 1.45805$ & $0.3743 \pm 0.31283$ \\
\hline
\end{tabular}

Spearman's correlation $\mathrm{r}=-0.693, \mathrm{P}=0.000$.

Statistical analysis. The significance of data was analyzed by the Chi-square test, Student's t-test, and correlation analysis using SPSS software, version 16.0 (SPSS, Chicago, IL, USA). $\mathrm{P}<0.05$ was considered statistically significant.

\section{Results}

Expression of PTCH and HHIP $m R N A$ in gastric cancer tissues. In this study, we first detected the expression of PTCH and HHIP mRNA in gastric cancer tissues and adjacent normal tissues and AGS gastric cancer cells by RT-PCR. The data showed that the positive rate of PTCH mRNA in gastric cancer tissues was $40 \%$ (12/30) compared to that of adjacent normal tissues $(83.3 \%, 25 / 30)$, while the positive rate of HHIP mRNA was 30\% (9/30) in gastric cancer tissue compared to that of adjacent normal tissues $(66.7 \%, 20 / 30)$ (Fig. 1 and Table II). Data from our qRT-PCR analysis were consistent with the RT-PCR data (Fig. 1D). We then associated PTCH and HHIP mRNA expression with clinicopathological data from the gastric cancer patients, and found that PTCH expression was associated with tumor differentiation $(\mathrm{P}<0.05$, Table III), but not with other factors, such as tumor stages or lymph node metastasis $(\mathrm{P}>0.05)$.

Expression of PTCH and HHIP proteins in gastric cancer tissues. Immunohistochemistry was performed to analyze the expression of PTCH and HHIP proteins in gastric cancer and adjacent normal tissues. Results showed positive staining of PTCH and HHIP proteins to be brown-yellow or brown granules, mainly expressed in the cell membrane, and rare in the cytoplasm (Fig. 2). We then associated the expression of PTCH and HHIP proteins with their mRNA levels and found a positive association between them (Pearson's test, $r=0.902$, $\mathrm{P}=0.000$ and $\mathrm{r}=0.935, \mathrm{P}=0.000$, respectively; Table IV). Statistical analysis was performed for the association between the expression of PTCH and HHIP proteins and clinicopathological characteristics. However, we did not find any statistical association, such as gender, age, TNM stage, tumor differentiation, and lymph node metastasis (Table V).

Detection of PTCH and HHIP gene promoter methylation in gastric cancer tissues. To investigate the mechanism underlying the loss of expression of PTCH and HHIP, we detected PTCH and HHIP gene promoter methylation in gastric cancer tissues. We detected HHIP gene promoter methylation by MSP. As shown in Fig. 3, a number of gastric cancer tissues had methylated HHIP gene promoters compared to adjacent normal tissues. We then associated HHIP gene promoter methylation with their mRNA expression and found that 


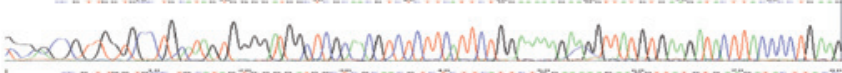

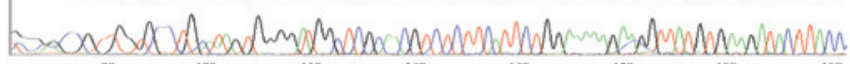

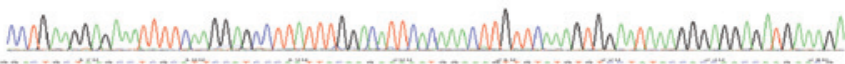

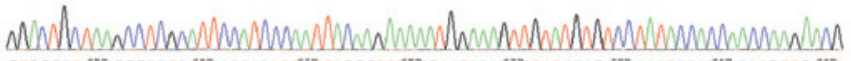

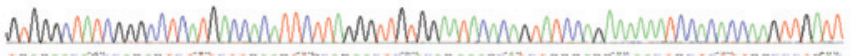

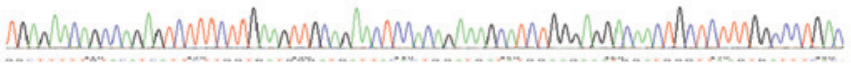

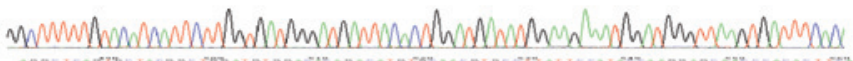

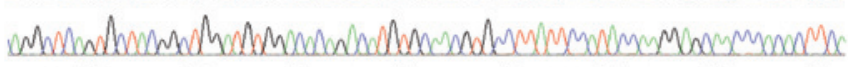

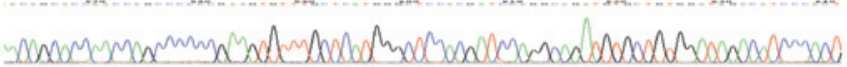

Figure 6. PTCH gene regulatory sequences on -870 to +229 bp section of the $19 \mathrm{CpG}$ sites within the methylation status of the bisulfite sequencing PCR (BSP) sequence analysis of the representative map.

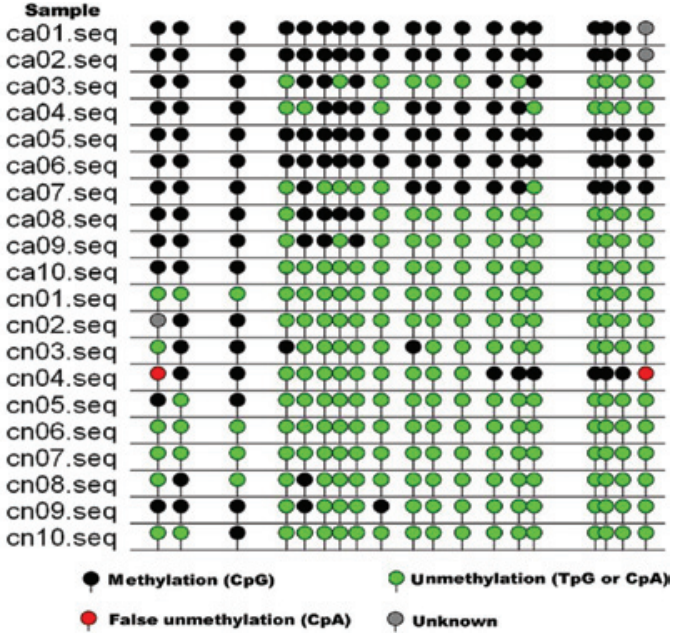

Figure 7. Methylation status of $19 \mathrm{CpG}$ dinucleotides in the promoter region of the protein patched homolog $(\mathrm{PTCH})$ gene. Each circle indicates a $\mathrm{CpG}$ site in the primary DNA sequence, and each line of circles represents the analysis of a single cloned allele.

Table VII. Reduction of cell viability by 5 -aza-dc treatment of gastric cancer cells.

\begin{tabular}{lcccr}
\hline 5 -aza-dc $(\mu \mathrm{M})$ & $\mathrm{N}$ & OD & P-value & t-test \\
\hline 0.5 & 3 & $0.8305 \pm 0.08756^{\mathrm{a}}$ & 0.017 & 3.514 \\
1.0 & 3 & $1.0295 \pm 0.04447^{\mathrm{a}}$ & 0.042 & 2.709 \\
2.0 & 3 & $0.8150 \pm 0.04272^{\mathrm{a}}$ & 0.001 & 6.957 \\
5.0 & 3 & $0.9933 \pm 0.03007^{\mathrm{a}}$ & 0.004 & 5.025 \\
10.0 & 3 & $1.2333 \pm 0.07932^{\mathrm{a}}$ & 0.403 & -0.913 \\
Control & 3 & $1.1652 \pm 0.03686$ & & \\
\hline
\end{tabular}

${ }^{\mathrm{a}} \mathrm{P}<0.05$, statistically significant.

Table VIII. Induction of apoptosis by 5-aza-dc treatment of gastric cancer cells (\%).

\begin{tabular}{lllr}
\hline 5 -aza-dc dose $(\mu \mathrm{M})$ & $\mathrm{N}$ & Apoptosis (\%) & P-value \\
\hline 0.5 & 3 & $15.52 \pm 0.28$ & 0.06 \\
1.0 & 3 & $15.89 \pm 0.09$ & 0.011 \\
2.0 & 3 & $33.39 \pm 0.4$ & 0.000 \\
5.0 & 3 & $23.44 \pm 0.38$ & 0.001 \\
10.0 & 3 & $16.11 \pm 0.08$ & 0.122 \\
Control & 3 & $14.51 \pm 0.25$ &
\end{tabular}

$\mathrm{P}<0.05$, statistically significant.

they were negatively associated (Spearman's test, $\mathrm{r}=-0.380$, $\mathrm{P}=0.000$ ). Fig. 4 shows the sequences of the methylated and unmethylated clones of the MSP product of the HHIP gene in gastric cancer; the arrows in Fig. 4A represent the methylated spots, while the arrows in Fig. 4B represent the unmethylated spots. As shown in Fig. 5 PTCH gene promoter methylation was identified by BSP. Furthermore, we performed bisulfite sequencing PCR analysis through Shanghai Sangon Co., and identified a negative correlation between PTCH expression and methylation (Spearman's correlation $\mathrm{r}=-.693, \mathrm{P}=0.000$, Table VI, Figs. 6 and 7).

Effects of drug 5-aza-dc on the regulation of gastric cancer cell viability and apoptosis. We evaluated a DNA demethylation agent, 5-aza-dc, on the regulation of gastric cancer cell viability using the MTT assay. Our data showed that different concentrations of 5-aza-dc reduced AGS cell viability (Table VII), and the optimal dose was $2.0 \mu \mathrm{m}$. The apoptosis 


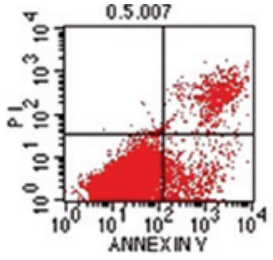

File: 0.5 .007
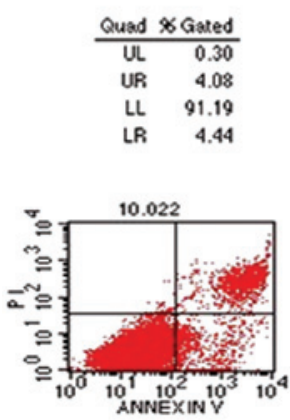

File: 10.022

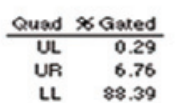

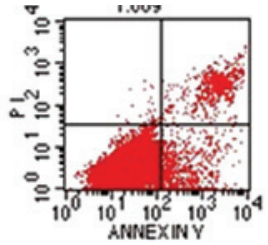

File: 1.009
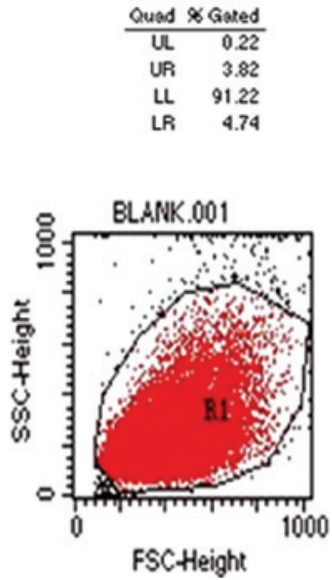

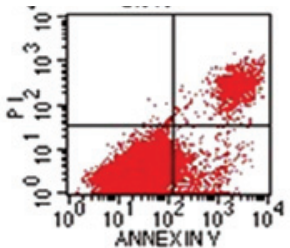

File: 2.013

\begin{tabular}{cr} 
Quad & $\$$ Gated \\
\hline UL & 0.20 \\
UR & 5.52 \\
LL & 89.86 \\
LR & 4.43
\end{tabular}
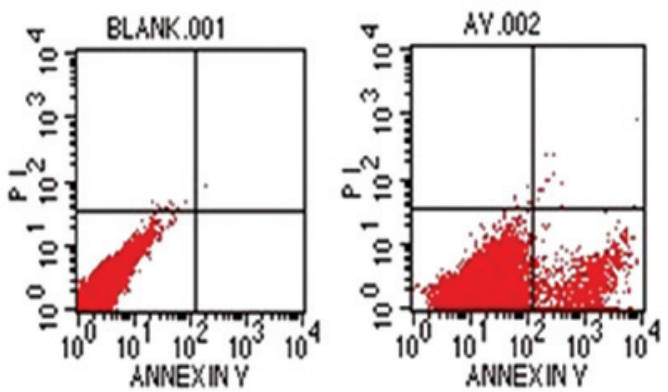

Figure 8. AGS cell apoptosis map with different concentrations of 5-aza-dc treatment.

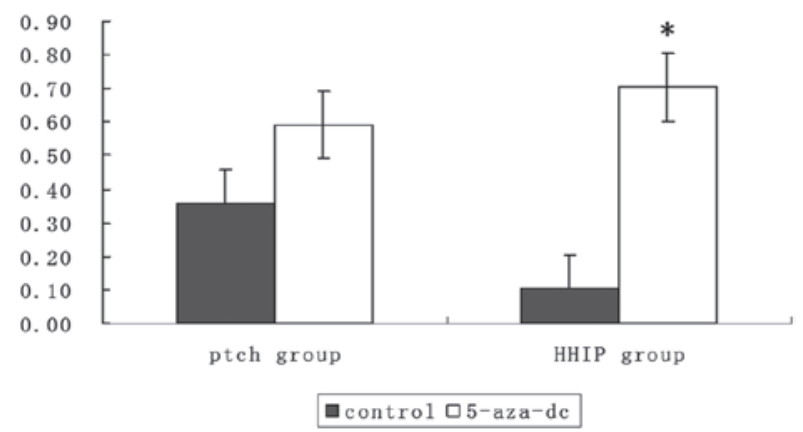

Figure 9. Protein patched homolog (PTCH) and human hedgehog-interacting protein (HHIP) expression with or without 5-aza-dc treatment.
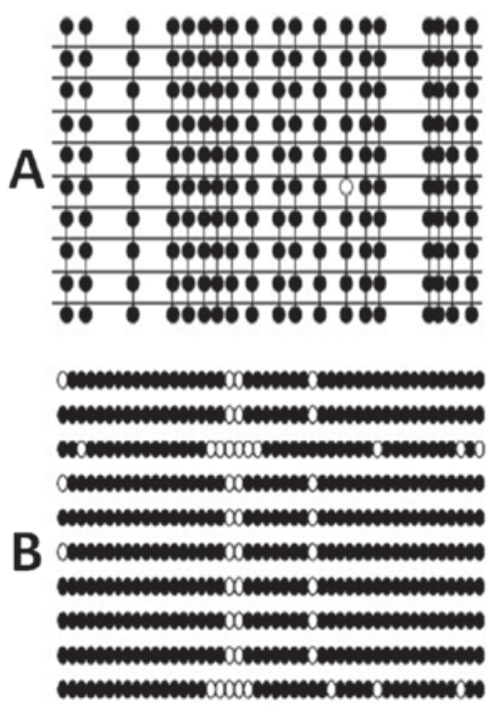

1

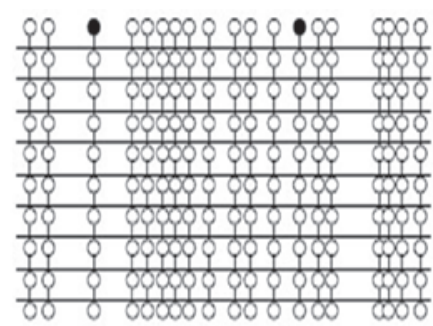

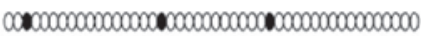

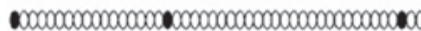
- 100000000000000000000000000000000000000 c) $\quad 0000000000000000000000000000000000$

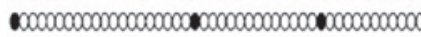

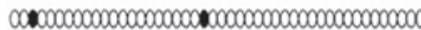

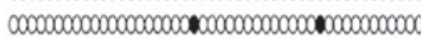

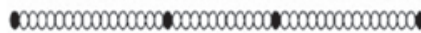

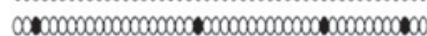

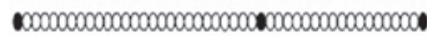

\section{2}

Figure 10. Methylation of protein patched homolog $(\mathrm{PTCH})$ and human hedgehog-interacting protein (HHIP) gene promoters in AGS cells was reversed by 5-aza-de treatment. (A) Methylation status of $19 \mathrm{CpG}$ dinucleotides in the promoter region of Ptched. (B) Methylation status of $46 \mathrm{CpG}$ dinucleotides in the promoter region of the HHIP gene. Each circle indicates a CpG site in the primary DNA sequence and each line of circles represents the analysis of a single cloned allele. 1, Without 5-aza-dc treatment; 2, with 5-aza-dc treatment; $\circ$, unmethylated; $\bullet$, methylated. 
rate was detected following treatment with 5-aza-dc and it was found that $2.0 \mu \mathrm{m}$ of 5-aza-dc significantly induced AGS cells to undergo apoptosis (Table VIII, Fig. 8).

To determine whether the effects of 5-aza-dc treatment occurred through upregulation of PTCH and HHIP expression, we assessed PTCH and HHIP expression. As shown in Fig. 9, PTCH and HHIP expression following treatment with 5-aza-dc was upregulated, and HHIP mRNA expression was much higher in the presence of 5-aza-dc treatment compared to no treatment $(\mathrm{P}<0.05)$. The expression of PTCH mRNA had no statistically significant changes. As shown in Fig. 10, methylation of PTCH and HHIP gene promoters in AGS cell was reversed by 5 -aza-dc treatment. The 5-aza-dc treatment lead to a marked decrease in the methylation of $\mathrm{PTCH}$ and HHIP gene promoters.

\section{Discussion}

In this study, we first analyzed the expression of PTCH and HHIP mRNA and protein in gastric cancer tissues and found that expression of the two genes was reduced in gastric cancer tissues compared to adjacent normal tissues. We also associated the expression of PTCH and HHIP protein with their mRNA levels and detected a positive association between them. Methylation of PTCH and HHIP gene promoters was identified and our data showed that a number of gastric cancer tissues have methylated PTCH and HHIP gene promoters compared to the adjacent normal tissues, which was inversely associated with expression of these two genes. Gastric cancer AGS cells were then treated with 5-aza-dc and it was found that 5-aza-dc reduced AGS cell viability and induce the cells to undergo apoptosis, which was associated with upregulation of the HHIP mRNA expression in AGS cells. Data from the present study indicate that PTCH and HHIP genes may be novel targets for the future control of gastric cancer.

The findings of this study on the reduced expression of PTCH and HHIP mRNA and protein are consistent with those of a previous study (22). Specifically, the Hedgehog family of ligand proteins appears to be important in the initiation of tissue repair, while the gastric epithelial cells are constantly replenished from progenitor populations, and these proteins are also essential for the regeneration process. However, aberrant expression and regulation of these proteins could alter homeostasis and neoplastic transformation of the stomach epithelium $(22,23)$. Nevertheless, our current data showed that expression of both PTCH and HHIP mRNA and protein are not associated with clinicopathological characteristics, such as gender, age, TNM stages, and lymph node metastasis, with the exception of the fact that expression of PTCH mRNA is associated with tumor differentiation in gastric cancer tissues. However, these data need to be confirmed using a large sample size.

We also determined the potential cause of the loss of PTCH and HHIP expression in gastric cancer tissues by examining their gene promoter methylation status. The findings of the present study show that PTCH and HHIP gene promoters were aberrantly methylated in gastric cancer, which was reversely associated with expression of their mRNA and proteins in gastric cancer. Moreover, we found that the degree of methylation of the two gene promoters in the gastric cancer AGS cell line was $99.7 \pm 0.67$ and $99.2 \pm 0.45 \%$, respectively. Specifically, methylation of gene promoters is a common epigenetic modification to silence gene expression, which is occasionally reversed using DNA de-methylation agents, such as 5-aza-dc. Thus, the reverse of HHIP and Ptched gene promoter methylation may provide a novel therapy for gastric cancer.

In vitro experiments were conducted to verify whether 5 -aza-dc was able to restore expression of the two genes via de-methylation of Ptched and HHIP gene promoters. The results showed that 5-aza-dc induced PTCH and HHIP expression, which was associated with a reduction in tumor cell viability and induction of apoptosis in AGS cells. Of note, the proportion of apoptosis was not associated with drug concentration. When the concentration of 5-aza-dc was 2.0 $\mu \mathrm{m}$, the apoptosis rate was significantly higher than at other concentrations. Furthermore, we analyzed the methylation status of $46 \mathrm{CpG}$ dinucleotides in the promoter region of the HHIP gene and the methylation status of $19 \mathrm{CpG}$ dinucleotides in the promoter region of the PTCH gene. We found that the demethylation reagent 5-aza-dc reversed the methylation of PTCH and HHIP gene promoters. Thus, we can conclude that methylation is the cause of downregulated PTCH and HHIP gene expression in gastric cancer tissue samples. DNA methylation is one of the most important mechanisms in the regulation of gene expression, and may also play a role in carcinogenesis. Our data suggest that the enhanced expression of PTCH and HHIP genes could strengthen the negative feedback function of PTCH and HHIP, which may provide novel targets for the future treatment of gastric cancer.

In summary, we have demonstrated that the silencing of PTCH and HHIP expression in gastric cancer tissue specimens is due to methylation of their gene promoters. Epigenetic reactivation of PTCH and HHIP expression likely modulates hedgehog pathway activity in gastric cancer. Thus, 5-aza-dc treatment was able to upregulate the expression of HHIP and PTCH genes and lead to a reduction in tumor cell viability and induction of apoptosis. Limitations of this study include its small sample size and the fact that it is not a molecular mechanistic study of PTCH and HHIP downstream genes.

\section{Acknowledgements}

We thank Medjaden Bioscience Limited for assisting in the preparation of this manuscript.

\section{References}

1. Parkin DM, Bray F, Ferlay J and Pisani P: Global cancer statistics, 2002. CA Cancer J Clin 55: 74-108, 2005.

2. Lum L and Beachy PA: The Hedgehog response network: sensors, switches, and routers. Science 304: 1755-1759, 2004.

3. Hooper JE and Scott MP: Communicating with Hedgehogs. Nat Rev Mol Cell Biol 6: 306-317, 2005.

4. Chaudary N, Pintilie M, Hedley D, Fyles AW, Milosevic M, Clarke B, Hill RP and Mackay H: Hedgehog pathway signaling in cervical carcinoma and outcome after chemoradiation. Cancer 118: 3105-3115, 2012.

5. Zardawi SJ, O'Toole SA, Sutherland RL and Musgrove EA: Dysregulation of Hedgehog, Wnt and Notch signalling pathways in breast cancer. Histol Histopathol 24: 385-398, 2009.

6. Pasca di Magliano M and Hebrok M: Hedgehog signalling in cancer formation and maintenance. Nat Rev Cancer 3: 903-911, 2003.

7. Katoh M: WNT and FGF gene clusters (Review). Int J Oncol 21: 1269-1273, 2002. 
8. Scherz PJ, Harfe BD, McMahon AP and Tabin CJ: The limb bud Shh-Fgf feedback loop is terminated by expansion of former ZPA cells. Science 305: 396-399, 2004.

9. Schnorrer F and Dickson BJ: Axon guidance: morphogens show the way. Curr Biol 14: R19-R21, 2004.

10. Han ME, Lee YS, Baek SY, Kim BS, Kim JB and Oh SO: Hedgehog signaling regulates the survival of gastric cancer cells by regulating the expression of Bcl-2. Int J Mol Sci 10: 3033-3043, 2009.

11. Tada M, Kanai F, Tanaka Y, Tateishi K, Ohta M, Asaoka Y, Seto M, Muroyama R, Fukai K, Imazeki F, Kawabe T, Yokosuka O and Omata M: Down-regulation of hedgehog-interacting protein through genetic and epigenetic alterations in human hepatocellular carcinoma. Clin Cancer Res 14: 3768-3776, 2008.

12. Chuang PT and McMahon AP: Vertebrate Hedgehog signalling modulated by induction of a Hedgehog-binding protein. Nature 397: 617-621, 1999.

13. Yoon JW, Kita Y, Frank DJ, Majewski RR, Konicek BA, Nobrega MA, Jacob H, Walterhouse D and Iannaccone P: Gene expression profiling leads to identification of GLI1-binding elements in target genes and a role for multiple downstream pathways in GLI1-induced cell transformation. J Biol Chem 277: 5548-5555, 2002.

14. Saqui-Salces M and Merchant JL: Hedgehog signaling and gastrointestinal cancer. Biochim Biophys Acta 1803: 786-795, 2010.

15. Cul'bová M, Lasabová Z, Stanclová A, Tilandyová P, Zúbor $\mathrm{P}$, Fiolka R, Danko J, and Visnovský J: Methylation of selected tumor-supressor genes in benign and malignant ovarian tumors. Ceska Gynekol 76: 274-279, 2011 (In Slovak).
16. Caffarelli E and Filetici P: Epigenetic regulation in cancer development. Front Biosci 16: 2682-2694, 2011.

17. Wolf I, Bose S, Desmond JC, Lin BT, Williamson EA, Karlan BY and Koeffler HP: Unmasking of epigenetically silenced genes reveals DNA promoter methylation and reduced expression of PTCH in breast cancer. Breast Cancer Res Treat 105: 139-155, 2007.

18. Pritchard JI and Olson JM: Methylation of PTCH1, the Patched-1 gene, in a panel of primary medulloblastomas. Cancer Genet Cytogenet 180: 47-50, 2008.

19. Fang JY and Xiao SD: Alteration of DNA methylation in gastrointestinal carcinogenesis. J Gastroenterol Hepatol 16: 960-968, 2001.

20. Cretnik M, Musani V, Oreskovic S, Leovic D and Levanat S: The Patched gene is epigenetically regulated in ovarian dermoids and fibromas, but not in basocellular carcinomas. Int J Mol Med 19: 875-883, 2007.

21. Sasaki M, Anast J, Bassett W, Kawakami T, Sakuragi N and Dahiya R: Bisulfite conversion-specific and methylation-specific PCR: a sensitive technique for accurate evaluation of $\mathrm{CpG}$ methylation. Biochem Biophys Res Commun 309: 305-309, 2003.

22. Merchant JL, Saqui-Salces M and El-Zaatari M: Hedgehog signaling in gastric physiology and cancer. Prog Mol Biol Transl Sci 96: 133-156, 2010.

23. Martin J, Donnelly JM, Houghton J and Zavros Y: The role of sonic hedgehog reemergence during gastric cancer. Dig Dis Sci 55: 1516-1524, 2010. 